Running Title: After Mazibuko

\title{
After Mazibuko: Exploring the responses of communities excluded from South Africa's water experiment
}

\author{
Nathan John Cooper ${ }^{\star}$ \\ University of Lincoln \\ nacooper@lincoln.ac.uk
}

\begin{abstract}
[Despite a constitutional right to water, challenges remain to achieving sustainable access tofor access to sufficient water for people in South Africa. This article considers the degree to which current legal and institutional provisions, understood within a paradigm of water commodification, perpetuate and embed approaches to water access, which are antithetical to genuinely eco-socio-sustainable water access. Water in South Africa has largely been re-cast as a commodity, exposed to market rules, proving problematic for many and giving rise to a variety ofvarious responses, including litigation. But-lin the seminal case of Mazibuko the Constitutional Court failed to provide robust protection or to adequately enunciate a substantive core to the right to water, providing= Such failure of "rights talk" has provided-impetus for the formation of "commons" strategies for water allocation. Indeed "commoning" is beginning to represent not only an emerging conceptual strand in urban resource allocation, but also a potentially-dynamic, contemporary, eco-sensitive, socio-cultural phenomenon, striving towardsdriving innovative, interactive and inclusive forms of planning and social engagement. Against the backdrop of unequal water access, commoning offers glimpses of an empowering and enfranchising subaltern paradigm replete with empowering and enfranchising potential. - reduce to 150 words please: 148 words now]
\end{abstract}

Keywords

Right to water, Constitutional Court, commons, IWRM, eco-socio-sustainable water

\section{INTRODUCTION}

The task of achieving sustainable access to sufficient water for everyone in South Africa is considerable. Water resource regulation during apartheid formalized and entrenched a profoundly unequal system, where white South Africans enjoyed an abundance of relatively cheap water, while the water supply for black South Africans

* Senior lecturer in law, University of Lincoln, Centre for Environmental Law and Justice. The author wishes to thank Profs Louis Kotze and Matthew Hall for their helpful comments on an earlier version of this article. All views and errors remain the author's. 
was impeded by poor infrastructure and lack of essential investment. ${ }^{1}$ Indeed, access to sufficient water became an avatar of the inequality and illegitimacy at the heart of the apartheid state, and a powerful trope to focus civil and political protest. The culmination of civil and political efforts to counter the systemic inequality of water access can be seen in the articulation of a specific right of access to water (alongside other essentials) in section 27 of South Africa's 1996 Constitution (the Constitution): "[e]veryone has the right to have access to sufficient food and water".

However, access to sufficient water is still not a reality for many, and multiple challenges, old and new, continue to impede the fulfilment of this most basic human need. ${ }^{3}$ Furthermore, those who regularly experience insufficient access to water inevitably also suffer from myriad associated consequences, including problems relating to health, as well as pressures on finance and time. Such personal and social consequences can only be understood by listening to the experiences or stories of "water-poor" people. This methodological approach, although commonplace in sociological work, remains under-used in legal research, but is one that this author deliberately adopts. ${ }^{4}$ Consequently, the stories around the responses of water-poor people to the shortcomings of "rights talk" are particularly important here to an understanding of the potential for commons modes of resource allocation, and to catalyzing a fresh perspective on the appropriate role of the courts, legislature and civil society in realizing sustainable access to sufficient water.

To this end, this article considers the legal, regulatory and institutional provisions relevant to achieving access to sufficient water, and considers the degree to which these continue to perpetuate and embed the discriminatory approaches of the past. In particular it analyses two phenomena, which are closely connected to the goal of access to sufficient water: water as a (human) right; and the commodification of water services. The right of access to water, as enshrined in the Constitution and as attested to in international law, is regularly cited as the catalyst and genesis of moves to combat water poverty and improve water access. However, this article reassesses the efficacy of this catalyst in light of recent judicial decisions, which, it contests, drain the right of its developmental potency, in the face of constrained "judicial managerialism". 5

The article examines the shift since 1994 towards commodification (and partial privatization) of water services in the country. It asserts that such a shift towards a new grundnorm in water services impedes progress, so badly needed, towards realizing access to sufficient water for all. Instead, stipulation of cost recovery for water services, and facilitating private and "privatesque" water service delivery, perpetuates asymmetrical power relations between suppliers and users, and encourages an understanding of water services that is antithetical to a paradigm of genuinely hydro-eco-socio-sustainable development. ${ }^{6}$

Moreover, the necessity of delivering sustainable access to sufficient water is compounded and contextualized by the emerging concept of social-ecological security, which attempts to articulate better the multifarious challenges to the security of the human (and non-human) environment. In particular it emphasizes

${ }^{1}$ P Bond "Water rights, commons and advocacy narratives" (2013) 29 South African Journal of Human Rights 125 at 128

${ }^{2}$ The Constitution of the Republic of South Africa, No 108 of 1996, sec 27(1)(b).

3 See discussion and statistics at points 7-10 of the General Household Survey 2013 (GHS 2013), available at: <http://www.statssa.gov.za/publications/P0318/P03182013.pdf> (last accessed 30 December 2016).

${ }^{4}$ See generally K Plummer Telling Sexual Stories (2004, Taylor \& Francis).

${ }^{5} \mathrm{~N}$ Cooper and D French "The right to water in South Africa: Constitutional managerialism and a call for pluralism" in E Blanco and J Razzaque (eds) Natural Resources and the Green Economy: Redefining the Challenges for People, States and Corporations (2012, Martinus Nijhoff ) 111 at 131

${ }^{6}$ N Nleya "Development policy and water services in South Africa: An urban poverty perspective" (2008) 25/3 Development Southern Africa 269 at 277 
that social and human security cannot be separated from environmental and ecological security. ${ }^{7}$ Therefore, not only must water services be "socio-sustainable" (sustainable from the perspective of human development), they must also be "eco-socio-sustainable" if they are to withstand the exigencies of planetary degradation. ${ }^{8}$ The concept (and imperative) of sustainable development is found in section 24 of the Constitution, the so-called "environment right". Section 24(b)(iii) states that everyone has the right to a protected environment, "for the benefit of present and future generations, through reasonable legislative and other measures that ... secure ecologically sustainable development ..." Promulgating legislation that aims to secure sustainable development in relation to water services has been heavily influenced by the approach of integrated water resources management (IWRM), as detailed below. However, realization of sustainable development in this area is inchoate at best, marking a serious shortfall in both judicial and legislative contributions to fulfilling people's right of access to sufficient water, both now and in the future. ${ }^{9}$

Together the failure of a rights centred approach to combating water poverty, and the effects of recasting water as a commodity rather than a basic necessity, are leading many to reprise "commons" strategies for water allocation that, while disparate in form and function, are increasing in prevalence. This article concludes by identifying some such strategies and exploring their current and potential roles. "Commoning" represents not only a (re)emerging conceptual strand in urban resource allocation, but also a dynamic, contemporary socio-cultural phenomenon, that strives towards innovative, interactive and inclusive forms of planning and social engagement. Against the backdrop of unequal water resources and exclusion, manifestations of commoning are being recognized and, with them, glimpses of a subaltern paradigm replete with empowering and enfranchising potential.

In this article, critical legal analysis of the right to water, promulgating legislation and policies is complemented and contextualized by reference to empirical research conducted in the city of Durban. Here, as elsewhere in South Africa, access to water for the urban poor is a constant struggle, compounded by moves to commercialize water services. The result is that access to water has emerged as a dividing line between those who can successfully navigate a private sector paradigm of resource allocation, and those who cannot but instead experience dislocation from the emerging norm and exclusion from what their constitution states is their right. Not only does this fusion of doctrinal and empirical research aim to convey better the experiences and responses of residents to water poverty, but it also seeks to remind us that access to (in)sufficient water is a human story, and our ability to realize the goal of access to sufficient water is a measure of our humanity: "[t]he human right to water is indispensable for leading a life in human dignity". ${ }^{10}$

\section{THE SHAPE OF WATER PROVISION IN SOUTH AFRICA}

${ }^{7} \mathrm{~J}$ Ebbesson "Social-ecological security and international law in the Anthropocene" in J Ebbesson et al (eds) International Law and Changing Perceptions of Security (2014, Brill) 71 at 77

${ }^{8}$ For more detail on this planetary perspective, see the emerging literature on the Anthropocene, beginning with [initial?] P. Crutzen and [initial?] E. Stoermer "The "Anthropocene" (2000) 41 IGBP Global Change Newsletter 17.

[work?] (2000, [publisher?]). They suggest that the Earth is moving into a critically unstable and inharmonious state as a result of the global human imprint on the biosphere and that concomitant social-ecological security issues are gaining renewed traction as scientists search for regulatory interventions to ensure social-ecological security amidst Anthropocene consequences.

${ }_{9}$ regulatory interventions to ensure social-ecological security amidst Anthropocene consequences. 9 The wording of sec $24(\mathrm{~b})(\mathrm{iii})$ consciously references the requirement of intergenerational equity, which is essential to any meaningful basic
definition of sustainable development. See World Commission on Environment and Development Our Common Future (1987, Oxford definition of sustainable development. See World Commission on Environment and Development Our Common Future (1987, Oxford
University Press) (Brundtland Report) at 43 .

${ }^{10}$ UN Committee on Economic, Social and Cultural Rights, General Comment 15: The right to water (29th session, 2003), UN doc E/C.12/2002/11 (2002), reprinted in "Compilation of General comments and general recommendations adopted by human rights treaty bodies", UN doc HRI/GEN/1/Rev.6 at 105 (2003) (General Comment 15). 
Any discussion of water rights must be framed within the reality that water in South Africa is a scarce resource. ${ }^{11}$ Increasing demand from urban centres for water for domestic use jostles with demands from industry, mining and agricultural sectors. These demands are made in a country where rainfall is lower than the global average and falls unevenly across the country. ${ }^{12}$ Over a decade ago, the South African Department of Water Affairs and Forestry warned of the unsustainable nature of water use: "[w]ith just $1200 \mathrm{Kl}$ of available freshwater for each person each year ... we are at the threshold of the internationally used definition of "water stress'. Within a few years, population growth will take us below this level. South Africa already has less water per person than countries widely considered to be much drier, such as Namibia and Botswana". ${ }^{13}$

With the advent of majority rule in 1994 it was clear that a significant change in the approach to water supply and water rights was necessary, based on the acceptance of two fundamental factors: the extreme inequality of water distribution (pre 1994) and the overall scarcity of water in terms of the total available to the country. A brief overview of South Africa's General Household Survey (2013) gives the most recent picture of the nation's access to water for domestic use. The percentage of households in Limpopo with access to water decreased from 84 per cent in 2010 to 77.5 per cent in 2013, making it the province in which households had the poorest access to water in $2013 .{ }^{14}$

Access in the Eastern Cape increased in the same period from 74.7 per cent in 2010 to 80.5 per cent in 2013. Access in other provinces in 2013 was as follows: KwaZulu-Natal 86.2 per cent; Mpumalanga 86.8 per cent; Western Cape 98.7 per cent; Free State 96 per cent; Gauteng 95.9 per cent; Northern Cape 96.3 per cent; and North West 88.4 per cent. Average access nationally in 2013 was 85.9 per cent. ${ }^{15}$

With a total population of $52,980,000,{ }^{16}$ this means that $7,470,180$ people lacked access to onsite or offsite piped or tap water in $2013 .{ }^{17}$ Of those who received piped water from a municipality, almost 25 per cent experienced interruptions in their piped water supply at least once a month. ${ }^{18}$ Access to sufficient water remains a significant stumbling block to both socio-economic development and political stability. ${ }^{19}$

These statistics only present a picture of people's access to water per se. They do not indicate the quantity of water people access and the reasons why. ${ }^{20}$ Consequently, the figure of 85.9 per cent of the national population that has access to water does not indicate that the same percentage of people have access to sufficient water as section 27 of the Constitution stipulates. This issue has significant bearing not only on people's general level of health and wellbeing, ${ }^{21}$ but has also been a key feature of the legal disputes over the constitutional

${ }^{11}$ M Kidd Environmental Law (2008, Juta \& Co Ltd) at 64.

${ }^{12}$ Ibid. [Which note? Above] at 64. [Ibid?]

${ }^{13}$ Department of Water Affairs and Forestry White Paper on a National Water Policy for South Africa (April 1997), para 14. The population of South Africa in 1997 was around 42 million. By 2013 the population had risen to nearly 53 million; see note 16 below.

${ }_{15}^{14}$ All percentages are from GHS 2013 , above at note 3 .

${ }^{15}$ Ibid.

${ }^{16}$ Statistics South Africa "Mid-year population estimates 2013", available at:

<http://www.statssa.gov.za/publications/P0302/P03022013.pdf> (last accessed 30 December 2016).

${ }^{17}$ Author's own calculation based on the figure for the total population of South Africa in 2013.

${ }^{18} 24.4 \%$, according to GHS 2013. Fieldwork undertaken by the author in February 2010 in Winterton in rural Kwa-Zulu Natal concurred that residents regularly experienced an interrupted water supply, with significant associated consequences for health and education, as well as discrimination (details on file with the author).

${ }^{19}$ A Russell Bring Me My Machine Gun: The Battle for the Soul of South Africa, from Mandela to Zuma (2009, Perseus Books).

${ }^{20}$ Neither do these statistics give any information on water quality. The Water Services Act, discussed below, aims to regulate water quality ${ }^{20}$ Neither do these statistics give any information on water quality. The Wa

as well as quantity (see GN R 509 Government Gazette, 8 June 2001, reg 5).
${ }_{21}$ P Bond and J Dugard "Water, human rights and social conflict: South African experiences" (2007) 1 Law, Social Justice \& Global

${ }^{21} \mathrm{P}$ Bond and J Dugard "Water, human rights and social conflict: South African experiences" (2007) 1 Law, Social Justice \& Global
Development Journal,1. Note also that fieldwork affirmed the connection between access to contaminated water and a range of health problems for residents interviewed in Winterton and Burlington f(see above at note 18)?]. Quality of water supply is also a crucial aspect of the definition of the human right to water as detailed by General Comment 15. 
provisions. "Sufficient water" has been quantified internationally to be between 20 and 50 cubic litres per person per day (lpd). ${ }^{23}$ In South Africa the ANC's Reconstruction and Development Programme (RDP) ${ }^{24}$ set sufficient water at a minimum quota of $25 \mathrm{lpd}$, available within 200 metres of a household.

As discussion below of the recent case of Mazibuko shows, defining sufficient water is problematic. However, a significant proportion of South Africans still do not even have access to the RDP quota of 25 lpd, 22 years after the formal end of apartheid. The recognition, promotion, protection and fulfilment of the right to sufficient water therefore remain crucial aims.

\section{SOUTH AFRICAN LEGISLATION AND REGULATION}

IWRM is an influential scientific approach to water management, which has provided the basis for water sector reform across the world, including shaping legislation in South Africa. As a systematic process for sustainable development, IWRM considers questions of water allocation within the contexts of economic and social development and environmental protection. Its central conceptual theme (that finite water resources are interdependent) leads to the conclusion that decisions about water use must involve all users, since they affect all users. Such an interconnected approach to water allocation encourages long term sustainability. It also incentivizes local self-regulation of water resources more effectively than central regulation and surveillance could. IWRM also recognizes the right of all people to clean water and sanitation at an affordable price. This right should be recognized first in all negotiations regarding water resources..$^{25}$

Two acts in particular have been promulgated in order to give effect to the constitutional right of access to sufficient water. The Water Services Act 108 of 1997 (WSA) is the principal legislative mechanism to actualize the state's obligations. The WSA aims to provide inter alia "the right of access to basic water supply and the right to basic sanitation necessary to secure sufficient water and an environment not harmful to human health or well-being". ${ }^{26}$ The act further addresses the social and ecological purposes of water respectively, setting "national standards and norms and standards for tariffs in respect of water services" and aiming "to promote effective water resource management and conservation" ${ }^{27}$ Basic water supply is defined in the WSA as "the prescribed minimum standard of water supply services necessary for the reliable supply of a sufficient quantity and quality of water to households including informal households, to support life and personal hygiene". ${ }^{28}$ The act sets the minimum quantity for basic water supply as 25 litres of potable water per person per

\footnotetext{
${ }^{22}$ See discussion below of Manqele and Mazibuko.

23 PH Gleick "The human right to water" (1998) 1 Water Policy [first page of article? 487 at 496.

${ }^{23}$ PH Gleick "The human right to water" (1998) 1 Water Policy [first page of article?] 487 at 496 . housing, water, electricity, telecommunications, transport, a clean and healthy environment, nutrition, health care and social welfare. The RDP's short term aim $f($ in art / sec? Section 2.6.6)t is to provide every person with adequate facilities for health. The RDP will achieve this by establishing a national water and sanitation programme that aims to provide all households with a clean, safe water supply of $20-30 \mathrm{lpd}$ within 200 metres, an adequate / safe sanitation facility per site and a refuse removal system for all urban households. In the medium term, the RDP aims $f($ Section art / sec? 2.6.7)\} to provide an onsite supply of 50-60 lpd of clean water, improved onsite sanitation and an appropriate household refuse collection system. A water supply to nearly $100 \%$ of rural households should be achieved over the medium term and adequate sanitation facilities should be provided to at least $75 \%$ of rural households. Community / household preferences an environmental sustainability will be taken into account. The RDP's long term goal f(Sectionin art / sec? 2.6.8) 7 is to provide every South African with accessible water and sanitation. See: $\quad<$ httn.//www (last accessed 1 introduction-rdp hettp: Januarytume 2017 )

$\frac{1622}{25}$ Januarytme 201ㄱ). , available at: <http://www.wmo.int/pages/prog/hwrp/documents/english/icwedece.html> (last accessed 30 ${ }_{26}$ December 2016).

${ }^{27} \mathrm{Id}$ Id, secs 2 (b) and 2(j)

${ }^{27} \mathrm{Id}, \operatorname{secs} 2$ (b) an
${ }^{28} \mathrm{Id}, \sec 11(1)$.
} 
day, or 6,000 litres per household per month. ${ }^{29}$ This minimum quota is to be provided free of charge and is designated as Free Basic Water. ${ }^{30}$ Water services authorities, including municipalities, are charged with a duty "to consumers or potential consumers in [their] area of jurisdiction to progressively ensure efficient, affordable, economical and sustainable access to water services". ${ }^{31}$ But there are no explicit provisions within the act on how "access" is to be achieved.

The National Water Act 36 of 1998 (NWA) is also important in implementing the constitutional right to water. The chief aim of this act is the protection of South Africa's water resources and, as such, the NWA adds ecological aspects of the right to water to the primarily social aspects stressed in the WSA. ${ }^{32}$ The coexistence of these two acts illustrates the importance of considering the socio-economic right to water within an environmental context that recognizes and responds to competing claims for scarce water resources (including domestic, industrial, human, non-human, present and future). Indeed, the NWA has been described as "the ecological grundnorm to facilitate access to water", ${ }^{33}$ setting the parameters within which sufficient water can be realised. However, the Constitution makes no mention of prioritizing either the right of access to sufficient water above the environment right or visa versa. Similarly the NWA receives no explicit authority above that of the WSA. There is therefore no legislative justification for limiting the social aspect of the right to water within the constraints of the NWA without acknowledging a corresponding need to view ecological priorities in light of the constitutional obligation to provide every citizen with access to sufficient water. The differing emphases of these two acts should not encourage incompatible agendas regarding water resources and water services. The WSA and the NWA must be read together, with the aim of facilitating access to sufficient water for all within the context of present and future ecological sustainability. ${ }^{34}$ The imperative of providing sufficient water to citizens now, provides a pragmatic framework within which ecological aspects of, inter alia, sustainability, conservation and biological diversity must be addressed..$^{35}$

The right of access to sufficient water requires a definition of sufficiency and access. Neither term is defined in the Constitution but, as already discussed, sufficient water has been defined in the literature variously as between 20 and $50 \mathrm{lpd}$ and has been defined legislatively as $25 \mathrm{lpd}$. Sufficiency has been described as being dependent on three factors: accessibility, adequate quality and adequate quantity. ${ }^{36}$ These factors encompass the

${ }^{29}$ WSA, Water Services Regulations, reg 3(b) in GN R 509, Government Gazette, 8 June 2001. The figure of 6,000 litres is based on 200 litres per household per day for each 30 day month. This assumes no more than eight people per household (200 litres divided by eight people is $25 \mathrm{lpd}$ ). The adequacy of the $25 \mathrm{lpd}$ minimum as well as the assumption of no more than eight people per household were considered in Mazibuko, discussed below.

${ }^{30}$ This commitment to free basic water was reiterated in the Free Basic Water Programme 2001Implementation Strategy 2007. See: f<http://www.gov.za/sites/www.gov.za/files/FBW\%20strategy\%20-

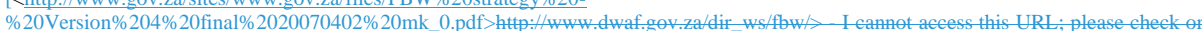
provide an alternative] (last accessed 22 June 201516 January 2017).

${ }^{31}$ The application of this duty on municipalities can be considered within the broader context of the onus on municipalities to provide basic services and realise basic socio-economic rights. Some commentators question to ability of municipalities to provide such services in the face of severely limited resources and capacity. Such constraints at the municipal level may significantly impair the state's ability to respect, protect, promote and fulfil the right to water as set out in WSA (and sec 27 of the Constitution). See generally AA Du Plessis Fulfilment of South Africa's Constitutional Environmental Right in the Local Government Sphere (2009, Wolf Legal Publishers).

${ }^{32}$ L Kotze "Access to water in South Africa: Constitutional perspectives from a developing country" (2009) 1 Ymparistojuridiikka ffirs page of article? 70 at 76

${ }_{33}^{3}$ Id at 79

${ }^{34}$ Ibid.

${ }^{35}$ The aims of the NWA are detailed in sec 2: "Ensure that the nation's water resources are protected, used, developed, conserved, managed and controlled in ways which take into account amongst other factors: (a) meeting the basic human needs of present and future generations; (b) promoting equitable access to water; (c) redressing the results of past racial and gender discrimination; (d) promoting the efficient, sustainable and beneficial use of water in the public interest; (e) facilitating social and economic development; (f) providing for growing sustainable and beneficial use of water in the public interest; (e) facilitating social and economic development; (f) providing for growing
demand for water use; (g) protecting aquatic and associated ecosystems and their biological diversity; (h) reducing and preventing pollution demand for water use; (g) protecting aquatic and associated ecosystems and their biological diversity; (h) reducing and preventing poll
and degradation of water resources; (i) meeting international obligations; (j) promoting dam safety; (k) managing floods and droughts."

${ }_{36}$ J Scanlon, A Cassar and N Nemes "Water as a human right?" IUCN Environmental Policy and Law Paper (2004) 51 at 28. 
five components of the human right to water as interpreted by the Committee on Economic, Social and Cultural Rights, namely that water must be sufficient, safe, acceptable, physically accessible and affordable. ${ }^{37}$

Together, the constitutional right of access to sufficient water and its promulgating legislation have framed the goal of realising access to sufficient water within a rights based approach. Individuals have the right of access to sufficient water. This right should be progressively realised, according to the state's available resources and subject to certain qualifications. Measures to ensure economic imperatives, social development and environmental protection are included in these instruments and recourse to restitution is available where individual rights are violated unreasonably (ultimately through litigation).

Section 39 of the Constitution (the constitutional interpretation clause) requires that a court, tribunal or forum must consider international law and may consider foreign law when interpreting legislation and when developing the common law and customary law. This provision means that the scope of, and discourse around, an internationally acknowledged human right to water is particularly pertinent to the domestic, constitutional position in South Africa.

\section{THE IMPACT OF AN INTERNATIONALLY ACKNOWLEDGED RIGHT TO WATER}

Despite not being explicitly mentioned as a human right in the Universal Declaration of Human Rights ${ }^{38}$ or International Covenant on Economic, Social and Cultural Rights, ${ }^{39}$ access to sufficient water has been progressively recognized internationally as a human right since the 1977 UN Water Conference in Mar del Plata. ${ }^{40}$ General Comment No 15, issued in 2002 by the Committee on Economic, Social and Cultural Rights, re-emphasized water as a prerequisite for the realization of other human rights and restated that access to water was itself a human right. ${ }^{41}$

In July 2010 the UN General Assembly adopted a resolution recognizing access to clean water and sanitation as a human right, ${ }^{42}$ further entrenching access to sufficient water as an internationally accepted human right to which the obligations of states parties to the International Covenant on Economic, Social and Cultural Rights apply. Compounding this clear declaration at the international level is the recently agreed goal 6 of the Sustainable Development Goals, to "ensure availability and sustainable management of water and sanitation for all" by $2030 .^{43}$

In South Africa, in addition to the right of access to sufficient water, ${ }^{44}$ other constitutional rights are related, directly or indirectly, to water access. These include the right to equality, ${ }^{45}$ right to human dignity, ${ }^{46}$ right to life,${ }^{47}$ property rights, ${ }^{48}$ right of access to housing,${ }^{49}$ rights of children, ${ }^{50}$ right to have access to courts, ${ }^{51}$

${ }^{37}$ General Comment 15.

${ }^{38}$ Adopted 10 December 1948, GA res 217A (III), 3 UN GAOR (resolutions, pt 1) at 71, UN doc A/810 (1948).

${ }^{39}$ Adopted 16 December 1966, 993 UNTS 3 (entered into force 3 January 1976), GA res 2200 (XXI), 21 UN GAOR supp (no 16) at 49, UN doc A/6316 (1966).

${ }^{40}$ Res II of the conference declared: "All peoples, whatever their stage of development and their social and economic conditions, have the right to have access to drinking water in quantities and of a quality equal to their basic needs."

${ }_{41}$ General Comment No 15, para 2: "The human right to water entitles everyone to sufficient, safe, acceptable, physically accessible and affordable water for personal and domestic uses." Para 1 exhorts states parties to "adopt effective measures to realise, without discrimination" the human right to water.

${ }^{42}$ UN GA10967, adopted 28 July 2010.

${ }^{43}$ See: <http://www.un.org/sustainabledevelopment/sustainable-development-goals/> (last accessed 30 December 2016).

${ }^{44} \operatorname{Sec} 27(1)($ b) of the Constitution: "(1) Everyone has the right to have access to: (a) health care services, including reproductive health care;

(b) sufficient food and water; (c) social security, including, if they are unable to support themselves and their dependants, appropriate social assistance."

${ }^{45}$ Id, sec 9 .

${ }^{46} \mathrm{Id}, \sec 10$

${ }^{47} \mathrm{Id}, \sec 11$

${ }^{48} \mathrm{Id}, \sec 25(8)$, regarding measures to achieve land, water and related reforms in order to redress the results of past racial discrimination. 
locus standi provisions ${ }^{52}$ and the environmental right. ${ }^{53}$ In short, access to sufficient water is an internationally accepted and nationally protected right for all people in South Africa, despite the fact that for many it is not a reality.

Consequently, discussion of access to sufficient water has been conducted largely using "rights talk": framing problems and obligations within a paradigm of individual rights. The case of Mazibuko illustrates the limits of rights talk in realising access to sufficient water. The case also highlights the courts' lack of consideration of sustainability, despite IWRM influenced legislation. Indeed the interconnectedness of social, economic and environmental factors that IWRM emphasizes seems to be recast here as three mutually excluding exclusive camps playing a zero sum game.

\section{THE LIMITS OF A RIGHTS CENTRED APPROACH}

Since majority rule, several cases have been litigated in relation to social and economic rights, including a small number of cases on the right to water. However discussion here will focus on the case of Mazibuko and Others $v$ City of Johannesburg and Others (Mazibuko $(W)),{ }^{54}$ which as will become apparent is the most important water related case to date. Mazibuko was first heard in the Witswaterand High Court and was brought by a group of residents from the Phiri area of Soweto, near Johannesburg. It challenged the legality of installing pre-payment water meters in light of the constitutional right to sufficient water. Installation was undertaken by the City of Johannesburg and its water company, Johannesburg Water, in response to acute water losses in Soweto as a result of corroded pipes, an inaccurate tariff system (that meant more water was used than was predicted to be necessary) and a "culture of non-payment" for water services that had "arisen originally as part of the resistance to apartheid local government". 55

The case examined the obligations of the City of Johannesburg and Johannesburg Water regarding access to water and the supply of free water for residents who cannot afford to pay. It was contended that, since pre-payment water meters, by design, require users to pay for water in advance, access to sufficient water is curtailed if users cannot afford to pre-pay. Such a situation was commonplace for Phiri residents and was raised as incompatible with the constitutional right to sufficient water. The WSA's quantification of sufficient water as a minimum standard of $25 \mathrm{lpd}$ was directly challenged in this case on the basis that what is a sufficient quantity of water depends on the requirements of users in particular social circumstances. For instance, people using waterborne sanitation require a greater volume of water to support life and personal hygiene than those using pit latrines. ${ }^{56}$ The High Court decision put great emphasis on the need to redress past injustices (as a result of apartheid policies) and the dire social and material state of many Phiri residents, described as "poor, uneducated, unemployed and ravaged by HIV / AIDS". 57

${ }^{49} \mathrm{Id}, \sec 26$

${ }^{50} \mathrm{Id}, \sec 28$

${ }^{51} \mathrm{Id}, \sec 34$

${ }^{52} \mathrm{Id}, \sec 38$

${ }^{53}$ Id, sec 24: "Everyone has the right (a) to an environment that is not harmful to their health or well-being; and (b) to have the environment protected for the benefit of present and future generations, through reasonable legislative and other measures that (i) prevent pollution and ecological degradation; (ii) promote conservation; and (iii) secure ecologically sustainable development and use of natural resources while promoting justifiable economic and social development."

${ }_{54}^{\text {promoting justifiable economic and social development." }}$

${ }^{54}$ Mazibuko and Others $v$ City of Johannesburg and Others (Centre on Housing Rights \& Evictions as amicus curiac
${ }_{5}^{5}$ Mazibuko and Others v City of Johannesburg and Others [2009] JOL 24351 (CC) (Mazibuko (CC)), para 166.

${ }^{56}$ Mazibuko and Others $v$ City of Johannesburg and Others [2009] JOL 24351 (CC) (Mazibuko (CC)), para 166.
${ }^{5}$ This is particularly pertinent to the interpretation of sufficient water in the Constitution, since sec 27 links food and water: "Everyone has ${ }^{56}$ This is particularly pertinent to the interpretation of sufficient water in the Constitution, since sec 27 links food and water: "Everyone has
the right to have access to ... (b) sufficient food and water". Also, since sanitation is not listed in sec 27 of the Constitution, but is

recognized as a right in WSA, sec 3(1), the volume of water that is sufficient must depend on the type of sanitation system being used.
${ }^{57}$ Mazibuko (W), para 5. 
In determining the applicants' grounds, the High Court looked to General Comment No 15 of the UN Committee on Economic, Social and Cultural Rights. ${ }^{58}$ Applying the General Comment, the court's view was that "the State is under an obligation to provide the poor with the necessary water and water facilities on a nondiscriminatory basis". 59

Moreover, the progressive realization of the constitutional right of access to sufficient water meant that: "[r]etrogressive measures taken by the state are prohibited. If such retrogressive measures are taken, the onus is on the state to prove that such retrogressive measures are justified with reference to the totality of the rights provided for in the [International Covenant on Economic, Social and Cultural Rights]. The state is obliged to respect, protect and fulfil the right to water." ${ }^{60}$

The installation of prepayment meters was held to be just such a retrogressive step, preventing residents from the access to sufficient water that they had previously enjoyed (before the prepayment meters, Phiri residents had access to a constant supply of water, despite many accruing arrears as a result). ${ }^{61}$ The retrogressive step was taken without adequate justification.

It was held that, given the particular needs of the Phiri community (including the need to use waterborne sewerage), a volume of $50 \mathrm{lpd}$ would be a more appropriate quantification of sufficient water than the statutory 25 lpd limit. Satisfied that the respondent could provide this increased amount "without restraining its capacity on water and its financial resources", ${ }^{62}$ the High Court decided wholly in the applicants' favour.

The City of Johannesburg and Johannesburg Water appealed to the South African Supreme Court of Appeal in February 2009. ${ }^{63}$ The quantity amounting to sufficient water for Phiri residents was reduced on appeal to 42 lpd. However, the High Court's approach was otherwise upheld, and the City of Johannesburg and Johannesburg Water were directed to formulate a revised water policy accordingly. ${ }^{64}$

Mazibuko in the High Court and Supreme Court of Appeal was heralded as an important milestone in socio-economic jurisprudence in South Africa. ${ }^{65}$ It showed the courts' willingness to push the legislature towards concrete manifestations of constitutional rights and not to allow the "progressive realization" of these rights to result in unconstitutional policies. The impetus to promote and fulfil the right of access to sufficient water was clearly discernible (particularly in Tsoka J's High Court judgment) ${ }^{66}$ in the acceptance of the need for sufficient water to be a quantity that promotes dignity and goes beyond the minimum of Free Basic Water already set. ${ }^{67}$ The potential implications of Mazibuko for people living in similar situations to the Phiri residents were significant. Both decisions demonstrated the courts' engagement with polycentric matters in order to help people to realize their socio-economic constitutional rights more quickly and more explicitly than would otherwise be the case. However, the environmental implications of Mazibuko may have been significant too,

${ }^{58} \mathrm{Id}$ at 106.

${ }^{59} \mathrm{Id}$, para 36.

${ }^{60} \mathrm{Id}$, para 37.

${ }^{61}$ Mazibuko $(W)$. Note that, before the installation of pre-payment meters and the associated improvements made to water pipes as part of the city's water services improvement project in Soweto (Operation Gcin'amanzi), water services were poor, but the volume of water available was unlimited (except when affected by intermittent technical problems).

${ }^{62}$ Id, para 181.

${ }^{63}$ City of Johannesburg and Others v Mazibuko and Others (Centre on Housing Rights \& Evictions as amicus curiae) [2009] JOL 23337

(SCA) (Mazibuko (SCA)).
${ }_{64}$ Id, summary. Note that, because the Supreme Court of Appeal found that 42 lpd was the quantity of sufficient water, not 50 lpd as decided ${ }^{64} \mathrm{Id}$, summary. Note that, because the Supten

\begin{tabular}{l}
${ }^{65}$ LJ van Rensberg "The right of access to adequate water: Discussion of Mazibuko v The City of Johannesburg case no 13865/06" (2008) 3 \\
\hline
\end{tabular} ${ }^{65} \mathrm{LJ}$ van Rensberg "The right of access to adequate water:
Stellenbosch Law Review ffirst page of article? 1415 at 434.

${ }^{66}$ See generally Mazibuko $(W)$.

${ }^{67} \mathrm{Id}$, para 1. 
potentially doubling the demand for water from a significant portion of the population, ${ }^{68}$ in a "water stressed" country. ${ }^{69}$

However, in September 2009 the Phiri residents appealed to the Constitutional Court (unhappy with the Supreme Court of Appeal's order to reduce the amount of water deemed to be sufficient from 50 to $42 \mathrm{lpd}$ ). This was the first time the Constitutional Court had considered the proper interpretation of the right of access to sufficient water. The Constitutional Court set aside the orders made by the High Court and Supreme Court of Appeal respectively.

The Constitutional Court held that the City of Johannesburg's Free Basic Water policy was not in conflict with section 27 of the Constitution or section 11 of the $\mathrm{WSA}^{70}$ and that the installation of pre-paid water meters was lawful. The court was satisfied that, while the Free Basic Water policy was flawed, it was consistent with the constitutional right of access to sufficient water. ${ }^{71}$ This was particularly so since the City of Johannesburg had continually amended its Free Basic Water policy during the course of the litigation. ${ }^{72}$ Consequently the applicants' appeal was dismissed, and the installation of prepaid water meters in Phiri was affirmed as compatible with section 27 of the Constitution. ${ }^{73}$

Crucial to this judgment is the guiding role that reasonableness has played in the Constitutional Court's jurisprudence since the seminal case of Government of the Republic of South Africa and Others $v$ Grootboom and Others (Grootboom). ${ }^{74}$ Although Grootboom related specifically to the constitutional right to adequate housing ${ }^{75}$ the standard established in this case required that government action in relation to socioeconomic entitlements generally, must be reasonable. Yacoob J defined reasonableness in Grootboom as follows: "[a] court considering reasonableness will not enquire whether other more desirable or favourable measures could have been adopted or whether public money would have been better spent. The question would be whether the measures that have been adopted are reasonable. It is necessary to recognize that a wide range of possible measures could be adopted by the state to meet its obligations". ${ }^{76}$

More detailed consideration of reasonableness as a legal principle is beyond the scope of this article. However what is prescient to the application of reasonableness by the Constitutional Court is that it allows for the accommodation of a legitimate diversity of views within the "limits of reason". 77

The principle of reasonableness was applied to the Constitutional Court's judgment in Mazibuko as follows. First, the nature of the right of access to sufficient water was accepted as being one of progressive realization. Secondly, the actions of the respondents (namely the City of Johannesburg and Johannesburg Water) in constantly reviewing their Free Basic Water policy, and providing on occasion for an additional free water allowance as well as relief from other municipal charges, together represent reasonable actions in relation to the

${ }^{68}$ Id at 1 136. para. 434 - is this page 136, para 434?

${ }^{69}$ M Kidd Environmental Law (2008, Juta \& Co Ltd) at 64.

${ }^{70}$ The duty on the part of the water services authorities to provide access to water services is clearly spelled out in WSA, sec 11(1): "Every water service authority has a duty to all consumers or potential consumers in its area of jurisdiction to progressively ensure efficient, affordable, economical and sustainable access to water services." Note that, while this duty is subject to a number of conditions including the availability of resources and the duty of consumers to pay reasonable charges ( $\sec 11(2))$, the WSA entrenched this duty by stating in sec 11(4) that a water services authority may not unreasonably refuse to give access to water services to a consumer or potential consumer in its area of jurisdiction. Further, in sec 11(5), the act states that in emergency situations a water services authority must take reasonable steps to

provide a basic water supply and basic sanitation services to any person within its jurisdiction and may do so at the cost of that authority.

${ }^{72}$ Mazid.

${ }^{72}$ Id, para 169.
Id

742001 (1) SA 46 (CC)

${ }^{75}$ The Constitution, sec 26.

${ }^{76}$ Grootboom, para 41.

${ }^{77}$ C Hoexter "The future of judicial review in South African administrative law" (2000) South African Law Journal 484 at 509. 
constitutional right to water, notwithstanding the respondents' continuing obligation towards progressive realization. ${ }^{78}$ The clear implication here is that, while the actions and policy of the respondents were deemed reasonable at the time of the judgment, they must not be allowed to solidify into an established standard. Rather, the impetus of progressive realization must engender continual revision. ${ }^{79}$

This application of reasonableness contrasts directly with the alternative approach to adjudicating on socio-economic rights that was followed by the lower courts in Mazibuko: namely establishing a minimum core obligation for the state to fulfil. Establishing the minimum quantum of water to be deemed sufficient, by reference to international standards and domestic, context specific evidence, ${ }^{80}$ would seem an appropriate approach to interpreting the constitutional right to water. So it is important to note the reasons that the Constitutional Court raised to vindicate its continued, deliberate and explicit rejection of a minimum core approach, in favour of reasonableness.

First, a constitutional defence can be made for the court's approach here. It reflects an impetus to maintain a clear separation of powers and to refrain from encroaching on matters of resource allocation, under the purview of the legislature and executive. ${ }^{81}$ Arguably, such a "restrained and focused role for the Courts" may help achieve "appropriate constitutional balance" 83 by avoiding direct incursion into budgetary and policy priorities: " $[\mathrm{t}]$ he Constitution does not require government to be held to an impossible standard of perfection. Nor does it require courts to take over the tasks that in a democracy should properly be reserved for the democratic arms of government" ${ }^{84}$

Secondly, the argument is made that quantifying a minimum core requirement here would detract from the duty imposed on government continually to review its policies to ensure the progressive realization of the right. ${ }^{85}$ Indeed, a situation could be envisaged where a defined minimum quantum of water may impede rights holders from receiving more than this quantum in keeping with the provider's capacity to supply. In order to avoid this, the court reiterates that it is for government to set the target it wishes to achieve, and for the courts to hold such a target to the standard of reasonableness. ${ }^{86}$

It is plausible to suggest that defining a (static) minimum core content to the right to water may have negative practical consequences in the future. Regarding this, the High Court and Supreme Court of Appeal decisions, to quantify the content of the right, without clarifying how a minimum core content relates to progressive realization, were unfortunate ${ }^{87}$ However it seems less plausible that a minimum core approach is necessarily incompatible with reasonable, progressive realization. Indeed there seems to be scope here to explore a mutually reinforcing model for these two principles, whereby a provisional minimum core is established, based on current capacity, but coupled with the requirement continually to pursue a fuller

${ }^{78}$ Mazibuko (CC), para 168.

${ }^{79} \mathrm{Id}$, para 163

${ }^{80} \operatorname{Mazibuko}(W)$, paras 128 and 172

${ }^{81}$ This reflects the High Court's approach in Manqele v Durban Transitional Metropolitan Council 2002 (6) SA 423. The volume of wate deemed sufficient for the purposes of sec 27 of the Constitution and sec 3 of WSA had not yet been prescribed. (The WSA had been enacted, but the associated regulations (GN R 509 of 8 June 2001) had not been promulgated). The court held that the minimum volume of water must be prescribed by regulation. In the absence of a regulation, the applicant relied on an incomplete right, rendering it unenforceable. Determining sufficient water was "a policy matter which falls outside the purview of the role and function of the court and is inextricably linked to the availability of resources": para 427

${ }_{82}$ Minister of Health and Others v Treatment Action Campaign and Others [2002] ZACC 15; 2002 (5) SA 721 (CC); 2002 (10) BCLR 1033

(CC) (Treatment Action Campaign No 2), para 38

${ }^{83}$ Ibid.

${ }^{84}$ Mazibuko (CC), para 161

${ }_{86}^{85} \mathrm{Id}$, para 67.

${ }^{86} \mathrm{Id}$, para 70

${ }^{87} \mathrm{Id}$, para 68 
realization of the right, to the extent that available resources allow. Such a hybrid approach would presumably require the periodic redefinition of the minimum core to reflect the progress made in realizing the right to date. Indeed, the degree of complementarity or antagonism between a reasonableness approach to socio-economic rights and a minimum core approach has been considered at length elsewhere and remains contested. ${ }^{88}$

Thirdly, it is asserted that a jurisprudence of reasonableness encourages a continuous contestation for the content of socio-economic rights, enabling "citizens to hold government accountable not only through the ballot box but also, in a different way, through litigation": 89 citizens and the courts combining in a dynamic, collaborative endeavour to negotiate what content the right (to water, in this case) should have at any one point in time. Indeed, the product of such litigation, according to O'Regan J, is to foster "a form of participative democracy". ${ }^{90}$ The clear implication here is that, if the court instead set an ultimate standard for such rights, government accountability would be affected and the citizens' role in the democratic process would be diminished. To this end the Constitutional Court maintained that litigation regarding the positive obligations of socio-economic rights was an important element of government accountability, concomitant with the founding provisions of the Constitution, "to ensure accountability, responsiveness and openness". ${ }^{91}$ Such litigation also complements the right of access to the courts in section 34 of the Constitution, to which Lindiwe Mazibuko and others were entitled as litigants: "[e]veryone has the right to have any dispute that can be resolved by the application of law decided in a fair public hearing before a court or, where appropriate, another independent and impartial tribunal or forum". ${ }^{92}$

Reading sections 1 and 34 together, the requirements of accountability, responsiveness and openness, and that of a fair public hearing, reflect much of the content ascribed by Bernstein to the value of fairness ("accountability, representation, and responsibility, as well as distributive justice"). ${ }^{93}$ When considered in the light of these standards, the Constitutional Court's judgment in Mazibuko has clearly facilitated government accountability by requiring "a detailed accounting from government". ${ }^{94}$ Furthermore, it has supported the representation of the applicants, by allowing their appeal, and clarified the responsibility of the City of Johannesburg and Johannesburg Water respectively. However, whether the judgment also achieved distributive justice remains contentious, as seen below.

The reasons set forth by the Constitutional Court in Mazibuko can be summarized as delivering a constitutionally deferent, pragmatic and conditional judgment that the actions of the water service providers regarding the claimants' right to water had been reasonable. Scholarly disagreement persists around the judgment. ${ }^{95}$ However, the explicit restatement of reasonableness as the appropriate approach to socio-economic rights litigation is perhaps understandable in a country with limited resources and manifold social and economic problems. Nevertheless, it emphasizes the tension at the heart of the justiciability of socio-economic rights: the pragmatism of progressive realization versus the necessity of immediate fulfilment. To those Phiri residents now

${ }^{88}$ D Bilchitz "Giving socio-economic rights teeth: The minimum core and its importance" (2002) 119 South African Law Journal 484 ${ }^{89}$ Mazibuko (CC), para 71

${ }^{90} \mathrm{Id}$, para 160.

${ }^{91}$ The Constitution, $\sec 1(\mathrm{~d})$

${ }_{92}^{92} \mathrm{Id}, \sec 34$.

${ }^{93}$ B Steven "Globalization and the requirements of 'good' environmental governance" (2005) 4/3-4 Perspectives on Global Development and Technology 645 at 652 .

${ }^{94}$ Mazibuko (CC), para 163

${ }^{95}$ See variously: LJ Kotze "Phiri, the plight of the poor and the perils of climate change: Time to rethink environmental and socio-economic rights in South Africa?" (2010) 1/2 Journal of Human Rights and the Environment 135; J Dugard "Can human rights transcend the commercialization of water in South Africa? Soweto's legal fight for an equitable water policy" (2010) Review of Radical Political Economics 1 . 
denied a quantum of water commensurate with their needs and necessary for their dignity, their right to water rings hollow.

The plight of the Phiri residents reflects the enduring reality of water poverty for people across the country, despite their right to water. In Durban, where the author's empirical work has focused, research on the city's experiment with water commodification ${ }^{96}$ reveals that the consequent impact of higher prices is disproportionately felt by those on low incomes. ${ }^{97}$ The following experiences of water poor residents are included to add a human face to these consequences. They record the reality of forced disconnections, which represent a regression in people's level of access to water and illustrate the dire choices forced on people whose access to water is insufficient and insecure:

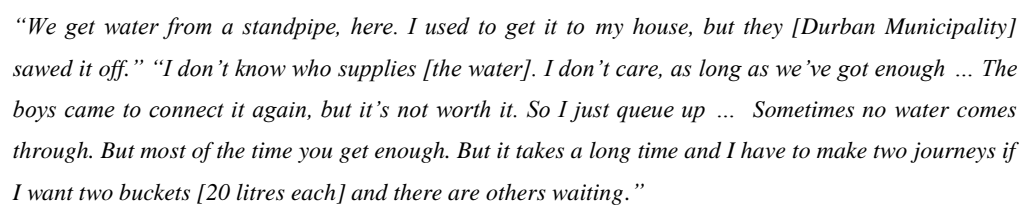

(Sanele, Burlington Township, Durban)

'Sometimes I can't go to the standpipe so I hope I've got enough water left from yesterday. If there's not much left I cook mieles [corn] or make tea, but don't sluice the toilet until the next day. I've got to eat first."

(Siyabonga Mbhele, Burlington Township, Durban) ${ }^{98}$

The social dimensions of these problems caused by access to insufficient water are obvious. However there are doubtless economic and environmental consequences too. Indeed the "Trinitarian" model of sustainable development, requiring consideration of social, economic and environmental factors, is central to an IWRM influenced approach to water allocation. It is visible to differing degrees in the courts' engagement with Mazibuko. However it is the social concerns of the Phiri residents pitched against the economic impetus of Johannesburg Water that are seen most clearly. The High Court and Supreme Court of Appeal afforded more weight to those social considerations of individual necessity for water and dignity; the Constitutional Court emphasized the nature of water as an economic good and the pragmatic limitations of progressive realization. The question of sustainability was raised before the Constitutional Court in relation to the ability of Johannesburg Water to provide a particular quantity of sufficient water per person. However this was clearly a question of economic sustainability linked to the assumption that the water provider must be able to operate

${ }^{96}$ Here, water commodification refers to the application of a commercial or private sector "mind set" to water services. This is characterized primarily by the experis prim expectation is not limited to water services provided by private companies, but is also now a common feature across state owned an provincial water providers. See generally DA McDonald and G Ruiters The Age of Commodity. Water Privatization in Southern Africa (2005, Taylor \& Francis)

${ }^{97}$ R Bailey and C Buckley "Modelling Domestic Water Tariffs" (presentation to Centre for Civil Society, University of Kwa-Zulu Natal, 7 November 2005).

${ }_{98}^{98}$ All quotations come from the author's interviews with residents during fieldwork between 2010 and 2015 (copies on file with the author).
Commented [W1]: I suggest just the first name is used, to respect privacy.
Commented [W2]: I suggest just the first name is used, to respect privacy. 
competitively. Concerns about environmental protection and the potential ecological implications of doubling the quantum of sufficient water were conspicuous by their absence from the High Court and Supreme Court of Appeal judgments. Neither court mentioned the environmental right (particularly sustainable development) in section 24 of the Constitution. ${ }^{99}$ Despite environmental protection and sustainability featuring heavily in the legislation, these considerations appeared in neither the obiter nor ratio of the Mazibuko judgments.

The absence of environmental considerations is common to rights talk in general, as individuals' rights claims are contested largely in isolation from the realities of resource scarcity. Such an atomized approach to rights adjudication emphasizes the very practical limitations to an anthropocentric human rights narrative. Yet, given the exigencies of water scarcity in South Africa, and more generally the Anthropocene challenges mentioned earlier, it seems essential that the focus of water access governance must be eco-socially sustainable. Stewart and Horsten's critique of this absence of environmental considerations in Mazibuko leads them to ask how and where water is used (60 per cent agriculture, 15 per cent industry etc), and the justification for such use in the face of the dual reality of water scarcity and insufficient water access for many. ${ }^{100}$ Such questions, if raised in the context of litigation, are likely to transgress the legitimate purview of the courts. However, when asked openly, they can aid the imperative of keeping social, economic and environmental aspects of water access interconnected.

A second critique is that adjudication of rights claims can remove their public, political dimensions, "domesticating issues of poverty" and casting them as private or familial matters. ${ }^{101}$ The limitations of a rights based approach to basic resource allocation are briefly sketched below.

A liberal analysis of the limitations of rights tends to focus on flawed implementation: sound ideas suffer from insufficient resources or poor application. However a radical critique suggests that the limitations of using rights to achieve genuine socio-economic improvements lie in the way that rights (internationally accepted human rights or constitutional rights) give moral claims legal form. In so doing the moral claim is diluted, turning it into a technical legal problem and bureaucratizing away the imperative to meet the claim on which the right is founded. ${ }^{102}$ When conceived as a legal problem, considerations like progressive realization, reasonableness and available resources become acceptable explanations for unmet claims. The moral claim that everyone should have access to the quantum of water required for dignified existence is immediately diminished because of the Constitution's limitations clause, which provides that the state can restrict rights if it is doing so reasonably. ${ }^{103}$ Similarly the Constitution provides for the progressive realization of socio-economic rights, but only within available resources. Lack of available resources is therefore a (legally) legitimate reason for unfulfilled rights, despite the size and nature of available resources remaining undisclosed. So, expressing the claim of access to water in legal form (as a right) creates practical difficulties, and allows for inchoate application. However there is also a normative dissonance between the moral claim and the narrative of a human right to water, particularly when interpreted in light of water commodification and privatization. As Karen Bakker explains: "[h]uman rights are individualistic, anthropocentric, state-centric, and compatible with private

${ }^{99}$ See note 53 above

${ }^{100} \mathrm{~L}$ Stewart and D Horsten "The role of sustainability in the adjudication of the right to access to adequate water" (2009) 24 South African Publiekreg/ Public Lan 486 a 503 .

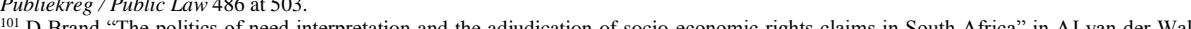
(ed) Theories of Social and Economic Justice (2005, African Sun Media) 17 at 35

${ }^{102} \mathrm{P}$ Bond "South Africa's rights culture of water consumption: Breaking out of the liberal box and into the commons?" (paper presented at Syracuse conference, Cape Town, February 2010) at 12.

${ }^{03}$ The Constitution, $\sec 36$ 
sector provision of water supply ... Moreover, 'rights talk' offers us an unimaginative language for thinking about new community economies ... occluding possibilities for collective action beyond corporatist models of service provision". ${ }^{104}$

Such a critique need not deny that the right of access to sufficient water has helped reduce the number of people living with insufficient water in South Africa. The right has had positive substantive and normative effects and has underpinned significant legal victories. ${ }^{105}$ However Pieterse ${ }^{106}$ and Bond ${ }^{107}$ assert that human rights generally, and constitutional rights specifically in South Africa concentrate on consciousness-raising and recognition of individual's rights to necessities, rather than focusing on redistribution, reparation and environmental exigencies. Their potential for social transformation is therefore limited. Countering these limitations is a growing cacophony of voices advocating for a paradigm shift, away from individualized rights, towards the "commons" and a culture of sharing, which is becoming known as "commoning".

\section{A RETURN TO THE COMMONS: LESSONS FROM DURBAN}

The Constitutional Court's decision illustrates the limitations of using rights to achieve real access to sufficient water. Unsurprisingly therefore, the strategy of campaigners, civil society and those affected by water poverty is changing in response. Reliance on litigation and an overly optimistic conception of the developmental role of the courts is being challenged and replaced. Instead, a shift is emerging towards advocating for greater grass roots, community action, aimed not at challenging the legality of inchoately experienced rights, but at reconfiguration at the community level, to address the underlying problem of water poverty. ${ }^{108}$ Some specific instances of such reconfiguration are discussed below. These are not a comprehensive survey of commoning in South Africa. They simply offer glimpses of a subaltern paradigm, which it is argued has the potential to combat water poverty more effectively than the status quo.

First, it is appropriate to offer a brief definition of the commons. The commons is a new way to express a very old idea, that some forms of wealth belong to us all, and that these community resources must be actively protected and managed for the good of everyone. ${ }^{109}$ To quote Bollier and Weston: "the Commons is not an ideological agenda or an impractical, utopian vision. It is a useful new / old framework and vocabulary for building a new societal vision and for imagining constructive alternatives to the neoliberal economics and policies that now enclose (commodify and privatise) shared resources ..."

As such, commons thinking seems well placed to critique the limitations and failures of existing "state / market"111 institutions and, in so doing, to create space to imagine and implement new forms of provisioning. Given its necessity as a prerequisite for life, water is increasingly being understood as one such form of wealth for which commons thinking seems appropriate. ${ }^{12}$ It is also becoming acknowledged that understandings of

${ }^{104} \mathrm{~K}$ Bakker "The 'commons' versus the 'commodity': Alter-globalization, anti-privatisation and the human right to water in the global south" (2007) 39/3 Antipode 441 at 447.

${ }^{105}$ See Residents of Bon Vista Mansions v Southern Metropolitan Local Council [2002] JOL 9513 (W).

${ }^{106}$ M Pieterse "Eating socio-economic rights: The usefulness of rights talk in alleviating social hardship revisited" (2007) 29 Human Right Quarterly 796 at 822.

${ }^{107}$ Bond "South Africa's rights culture", above at note 102

${ }^{108}$ See Socio-Economic Rights Institute of South Africa website: 〈http://www.seri-sa.org〉 (last accessed 30 December 2016).

${ }_{109}$ [<http://www.onthecommons.org/eontent.php?id=1467> I I cannot access this URL; please check or provide an alternative] (last accessed 31 December 201516 January 2017).

${ }_{110}^{\text {accessed }} 31$ December 201516 January 2017$)$. and E Grant (eds) Thought, Law, Rights and Action in the Age of Environmental Crisis (2015, Edward Elgar) 251 at 252

${ }^{111}$ Id at 251 . Here the term "state / market", used by Bollier and Weston, indicates the close relationship between the institutions of state and market, which reflects a shared commitment to a neoliberal political and economic agenda.

${ }^{112}$ See: $<$ http://www.ourwatercommons.org> (last accessed 30 December 2016) 
water that are limited to discourses of water rights and water commodification, perpetuate an unsustainable and unhelpful "bifurcation between nature and culture", ${ }^{113}$ which must be creatively reimagined.

In contrast to individualized consumption within a rights based paradigm, a commons strategy emphasizes shared consumption. This echoes the emphasis on interconnectivity within IWRM. However, unlike IWRM, a commons strategy avoids emphasizing individual water rights, in favour of communal needs. This shift in focus may offer a more effective model of implementing sustainable water allocation, while avoiding the pitfalls of rights talk inherent in the right to water. A commons strategy would encourage decisions on water allocation to be made at the lowest appropriate level, involving all users inputting into collective decisions that transcend a compromise of competing interests, in favour of corporately "owned" allocation decisions that best serve each community.

One small example of such a commons approach to water resources can be seen in Burlington, in eThekwini municipality, on the outskirts of Durban. Although the municipality had provided piped water to a number of homes here, the cost of water from this source quickly proved prohibitive for many residents. They became indebted and eventually the pipes were disconnected. The author first visited Burlington in February 2010, as part of empirical research to talk to residents about their experiences of access to water. He saw and heard how the community, many of whom had had their water supply disconnected, had organized themselves into those who were able to collect water from the standpipe (both those physically able and those who had time) and those who could not. Those not able to use the standpipe (including older residents) were receiving a small amount of money from their younger neighbours in order to ensure that their water bills were paid and that they could continue to enjoy water piped to their homes, while able bodied residents relied again on the standpipe. Community leaders met to decide who to prioritize in this system and to monitor how it worked.

More recently, in November 2015, the author revisited this community to find that access to sufficient water remained a daily challenge for many. However, once again this problem has led several households to develop an innovative response. Standpipes remain the primary means of accessing water for many in this community. They are fed by long pipes, dug into shallow troughs or running along the surface of the ground. A number of residents living near these pipes have plumbed in to them in order to connect a water supply directly to their homes. However, in so doing, water pressure for the standpipe is reduced, and those residents who continue to rely on water from the standpipe experience periods when little or no water is accessible: "[it is] a struggle because the water can't come out because and all of these people are like taking water in to their house and no water is coming out the standpipe". ${ }^{114}$

Acknowledging that, for many South Africans, piped water is not a reliable source, the government launched the "adopt a river" initiative in $2010 .{ }^{115}$ This combines education to reduce river pollution with training and equipment to clean and maintain rivers for use as sources of water for communities living close to them. Burlington is one such area and, in 2013, 60 residents volunteered to clean and maintain their local river. Every week volunteers continue to maintain their section of the river, without any ongoing support from government, and create a safe alternative to using standpipes for those still living without piped water to their homes. In the midst of poverty and hardship, and faced with a regression in their level of access to water,

${ }^{113}$ A Neimanis "Alongside the right to water, a posthumanist feminist imaginary" (2014) 5/1 Journal of Human Rights and the Environment 5 at 5 .

${ }_{114}^{114}$ Author's interview with Thembeka, a resident of Burlington Township, Durban, November 2015 (copy on file with the author).

${ }^{115}$ South African Water Research Commission "Adopt-a-River launches in Limpopo and KwaZulu-Natal” (31 August 2010), available at: <http://www.wrc.org.za/news/pages/adopt-a-riverlaunchesinlimpopoandkwazulu-natal.aspx> (last accessed 30 December 2016). 
residents in Burlington chose to engage with the problem of water poverty from the perspective of shared needs, rather than focusing on their individual rights, and what can be described as commons ideas are beginning to take root in this community. ${ }^{116}$

Similarly, recent research undertaken elsewhere in eThekwini (Durban) municipality suggests that water poor residents are adopting an approach to water allocation that emphasizes a responsibility to each other, in contrast to the individualistic paradigm reinforced by an unreconstructed notion of a right to water. ${ }^{117}$ This municipality is considered a leader in sustainable water services. Initiatives to reduce water wastage and improve water quality have been pioneered by the municipality, with considerable success. ${ }^{118}$ Between 1999 and 2009 water was brought to over a million people who previously lacked it. ${ }^{119}$ Such an approach, driven in large part by municipal and state strategic goals, has been assisted in no small part by the prevailing mindset of residents, who fuse a strong ethic of individual responsibility for water use with an understanding of water as a common resource.

On a larger scale, the Durban Group for Climate Justice, ${ }^{120}$ formed in 2004, has proved to be an important practical and intellectual focal point for community organization and action, including in relation to water allocation issues. However perhaps more importantly, this civil society movement has galvanized disparate single issues around a coherent aim of climate justice. ${ }^{121}$ Echoing previous discussion of the indivisibility of human security from ecological security, and of social from economic from environmental sustainability, the Durban Group for Climate Justice has successfully directed public energy and community involvement around the coherent but multi-dimensional goal of pursuing climate justice at every appropriate scale: promoting a truly common endeavour.

Each of these commons approaches seem to contain not only the necessary appreciation of water as a shared resource, but also a strong social conscience that may prove capable of overcoming the perceived weaknesses famously identified in Garrett Hardin's pessimistic treatise "The tragedy of the commons". ${ }^{122}$ The central problem of the commons is described as follows by pioneering commons scholar Elinor Ostrom: "[h]ow a group of principals who are in an interdependent situation can organize and govern themselves to obtain continuing joint benefits when all face temptation to free-ride, shirk or otherwise act opportunistically". ${ }^{123}$

These examples, from Burlington in particular, illustrate this tension between cooperation and self interest, which any endorsement of commons approaches must acknowledge. In that community, the challenge of securing access to sufficient water is being met variously by those prioritizing sustainable access for the community at large, and by those whose independent action to pipe water to their own homes leaves their neighbours without.

Perhaps such examples of commoning, or commons thinking, are too ephemeral to categorize or concretize formally. Indeed the community's attitudes and response in Burlington have very little rigid structure

${ }^{116}$ Taken from interview transcripts during fieldwork in South Africa (February 2010) (copies on file with the author).

${ }^{117}$ S Hellberg "Water life and politics: Exploring the contested case of eThekwini municipality through a governmentality flense does the original read "lens"?]" (2014) 56 Geoforum 226 at 230

${ }^{118}$ In 2014 eThekwini Municipality won the Stockholm Industry Water Award. See [<http://www.siwi.org/prizes/winners/2014-2 http://www siwi.org/prizes/stockholmindustrywateraward/winners/2014 2h> I cannot access this URL; please check or provide at alternative] (last accessed 28 January 201616 January 2017).

${ }_{119}^{\text {ald }}$ at 228.

${ }^{119}$ Id at 228.
${ }^{120}$ See: <https://www.tni.org/en/profile/durban-group-for-climate-justicehttp://www.durbanclimatejustice.org> (last accessed 30 December

${ }_{121}^{2016) .}$ Bond "Water rights, commons", above at note 1 at 140

${ }^{122} \mathrm{G}$ Hardin "The tragedy of the commons" (1968) 162 Science 1243.

${ }^{123}$ E Ostrom Governing the Commons: The Evolution of Institutions for Collective Action (1990, Cambridge University Press) at 42. 
with which to ensure that future challenges will be met using the same commons approach (although it must be noted that there have been moves towards identifying specific members as decision makers). However this lack of rigid structure should not lead us to conclude that commons approaches lack resilience, nor that they will necessarily be temporary. Rather, it is precisely the relative lack of formalized structure which may allow such commons approaches to withstand changing environments and challenges. Ostrom's insights are particularly pertinent here, as she explains that, traditionally, advocates of state resource allocation and advocates of privatization have both relied on the assumed superiority of top down institutional design. Institutional change, it is assumed, (including that required to give effect to the right to water) must come from outside the community and be imposed on those individuals affected. ${ }^{124}$ This assumption rests in turn on a further assumption, that there is a dichotomous choice to make between these two top down modes: state or private control must be the correct route. The benefit of commons approaches, manifest in more or less fluid form, is that they are well placed to fill the gaps between competing regulatory approaches, which almost inevitably appear while the question of (water) resource allocation is being inadequately addressed through the complex, overlapping, sometimes competing paradigms of rights, development and commodification. Ostrom's vision here is to see the creation of a "rich mixture of 'private-like' and 'public-like' institutions defying classification in a sterile dichotomy". ${ }^{125}$ Such a definition is not out of place in describing the various commons approaches observed above. Indeed "adopt a river" initiatives, pioneered in eThekwini, provide useful examples of precisely such a classification defying hybrid: a mixture of public resources catalysing community action.

Romanticizing community control of resources must be avoided, not least because small as well as large scale inequitable power relations can exist. Therefore there is potential for any institutional design and praxis to discriminate and disenfranchise. Also, it must be acknowledged that commons endeavours face myriad challenges around resourcing and sustainability, as well as the ever present possibility that people will default to opportunistic (in)action. Burlington's adopt a river initiative, described above, began with 60 volunteers. In November 2015 there were only ten.

While we must be mindful of these problems, commons ideas are on the rise. ${ }^{126}$ This is driven, in part, by the failures of litigation on the right to water, and of "rights talk" more generally, to incorporate environmental protection, and even to deliver resources to all individuals effectively. Indeed, what the Constitutional Court has identified as a crucial function of litigation on social and economic rights ${ }^{127}$ (to provide crucibles within which new socio-economic settlements are created and recreated) is also a function that may be ascribed to the commons. The commons may contain a degree of potential for positive change, which the court's jurisprudence of reasonableness has so far failed to deliver: "[i]n a commons, ordinary people can deliberate with each other and have their concerns heard ... to formulate and ratify the rules that will affect their everyday lives". ${ }^{128}$

Commons strategies, if innovatively applied to water allocation, may be able to avoid the limitations of the right of access to sufficient water, restating sufficient water as a moral claim, made corporately by and for people within their community. Commons solutions, whether long lasting or temporary, have the potential to give form to the erstwhile unheard voices of the water poor and to respond appropriately through innovative and inclusive social / institutional arrangements. Given the social, economic and environmental imperative for

\footnotetext{
${ }^{124} \mathrm{Id}$ at 14.

${ }^{125}$ Ibid.

${ }^{126}$ Bond "Water rights, commons", above at note 1 at 138

${ }_{127}^{127}$ Mazibuko (CC), para 71 .

${ }^{128}$ Bollier and Weston "Reimagining ecological governance", above at note 110 at 254.
} 
sustainability that any commons strategy must consider, IWRM too could find its functional imperative of sustainability rejuvenated beyond the limitations of rights talk. 